ARTICLE

\title{
Comparative Evaluation of Productivity and Cost Effectiveness of Catfish Fingerling Production in Earthen Pond and Recirculation System in Ibadan, Nigeria
}

\author{
*ADEYEMO, O. K., GANIYU, O. I. and OLUGASA, B.O.
}

Department of Veterinary Public Health and Preventive Medicine, University of Ibadan, Ibadan, Nigeria.

*Email: olanikeadeyemo@hotmail.com, olanike.adeyemo@mail.ui.edu.ng Tel: +234-805-545-4544,

\begin{abstract}
SUMMARY
Despite the popularity of the African catfish and its great market potentials, the production is still basically at subsistence level due majorly to inadequate supply of seed for stocking. This has been linked to the absence of reliable production techniques for the mass production and rearing of the species under practical farming conditions. The purpose of this study therefore, was to find a suitable culture system for the mass production of caffish (Clarias gariepinus) fingerlings. Protected earthen pond and a unit of recirculation system were used. Fertilized eggs from female were divided into two equal halves and incubated under the same conditions. Forty-nine thousand frys each were stocked into the protected earthen pond and a unit recirculation system respectively. The frys in the two systems were raised for twenty one days and fed the same quantity and quality of feed throughout the period. The survival rate of the frys in the recirculation system was $79 \%$ as against $17 \%$ in the earthen pond. However, bigger sized $(2.2 \pm$ $0.23 \mathrm{~g}$ ) fingerlings were obtained from the earthen pond relative to those cultured in the recirculation system $10.9 \pm$ $0.07 \mathrm{~g}$ ). The cost of raising frys in a recirculation system ( $(\mathrm{N} 3,000)$ was twice that needed for earthen pond $(\mathrm{N} 17,000)$, but this was more than made up for in the profit from sales, which was N311,360 and N99,156 respectively. The main reason for fish farming is the expected return to be, therefore, the choice of income-generating activities, amongst several options available, should be made on the grounds of their expected returns.
\end{abstract}

KEYWORDS: Aquaculture, Fingerling Production, Clarias gariepinus, Recirculating system, Earthen Pond

\section{INTRODUCTION}

Aquaculture in Nigeria has remained low despite the huge potential that exists in the country. Currently, earthen ponds are the dominant production system in Nigeria (FAO, 1999, Adeyemo and Falaye, 2009). A major proportion of public sector research and development effort has been directed towards increasing the productivity of pond systems. In contrast, very little public sector research and development has been geared towards improving and understanding other production systems. In order to increase the production potential of aquaculture in Africa, research and development should focus on a wider range of production systems for fish farming and on increasing the intensity of production in fish ponds to help farmers achieve higher yields (Hecht, 2000).

The worldwide practice of aquaculture runs the gamut from low-technology extensive methods to highly intensive systems. At one extreme, extensive aquaculture can be little more than contained stock replenishment, using natural bodies of water such as coastal embankment, where few if any alterations of the environment are made. Such culture usually requires a low degree of management and low investment and operating costs; it generally results in low yields per unit area (Watanabe et al., 2002). At the other extreme, intensive aquaculture, animals are grown in systems such as tanks and raceways, where the support parameters are carefully controlled and dependence on the natural environment is minimal. Such systems require a high degree of management and usually involve substantial investment and operating costs, resulting in high yields per unit area. Managed ecosystems form the basis for aquaculture production, which has been widely offered as a means to compensate and ultimately supplement traditional fisheries (Pillay, 1990). Here, unlike fisheries, inputs, production processes and quality of output can be at least 
partially controlled, and ownership, care and environmental responsibility might be more easily established.

The development of a reliable method for the mass production of Clarias gariepinus fingerlings for constant supply is important. In Europe, about $75 \%$ of Clarias fingerling demands are supplied by few producers. In Nigeria however, the fingerlings supplied from both the government and privately owned hatcheries are not enough to meet the catfish farmers' fingerling demands (Olaleye, 2005). A comparative evaluation of productivity and cost effectiveness of catfish fingerling production in an earthen pond and a recirculation system was therefore carried out in Ibadan, Nigeria.

\section{MATERIALS AND METHODS Selection of breeders}

Two year old male and female parent stocks were selected from the brood stock pond and weighed. The female was selected because of its protruded abdomen and egg viability was based on the size of the eggs and the uniformity of egg in terms of colour, consistency and size. Likewise the male was selected on the basis of age, the redness and the length of its papillae. The gravid female weighed $1.8 \mathrm{~kg}$ and the male $1.4 \mathrm{~kg}$; they were both kept in separate tanks and fasted for 24 hours to ensure that the guts are free of feed.

Preparation and injection of pituitary extract A fresh pituitary gland collected from a female fish weighing $2.1 \mathrm{~kg}$ was macerated in a tissue homogenizer with $2 \mathrm{ml}$ normal saline solution. The prepared solution was centrifuged and the supernatant was injected intra-muscularly above the lateral line into the female fish. Fish were kept in tanks at $25^{\circ} \mathrm{C}$ for 15 hours before stripping.

Egg fertilization, incubation and collection of fry Prior to egg stripping, the male brooder was sacrificed and the testes were harvested. The milt was extracted by crushing the testes and squeezing milt into $0.9 \%$ normal saline. After which the female brood stock was striped and the eggs collected in a dry plastic container. The eggs were weighed on a kitchen scale $(400 \mathrm{~g})$ and divided into two equal halves. Milt was added to the eggs in the separate containers and mixed together using plastic spoon. The eggs were spread differently in two separate incubators on egg trays. Hatching was completed after 26 hours, after which the egg tray was lifted. The hatchlings were siphoned out of their respective incubators into a new tank containing clean water and were allowed to stay for 3 days before being transferred into prepared earthen ponds and re-circulating system respectively.

\section{Preparation and stocking of earthen pond and recirculation system}

A 33 X 33 X 2 feet pond was drained and desilted; also the bush around the pond was cleared and the pond lined with hydrated lime. After 3days, the pond was re-drained to get rid of the limed water and the pond was fertilized and netted to keep off predators. A unit of recirculation system was also washed and all accessories properly arranged. The recirculation system was made to operate for two days prior to stocking to ensure that the system was working properly. Forty-nine thousand 3- day old fry from the nursery tank were simultaneously stocked in the two systems and fed shelled dry Artemia salina for the first two weeks and $0.3-0.5 \mathrm{~mm}$ sized dry pellets the third week before they were harvested on day 21.

Fish in the earthen pond and recirculation system were thoroughly monitored. Recirculating system was siphoned to remove waste and feed remnants, while shooters were removed with nets everyday from both earthen pond and recirculating system to prevent cannibalism. Profit was calculated by subtracting expenditure incurred from production in each system from the sale of juveniles.

\section{RESULTS}

The sizes of the juveniles from the earthen pond and recirculation system after the culture and the comparative values of the parameters investigated are presented in table I. The cost analysis for the nursery rearing of catfish within protected earthen pond and recirculating system is in table II; while the comparative profit margin of nursery rearing of catfish within protected earthen pond and recirculating system is in table III. 
Table I: Comparative values of parameters investigated in the Protected Earthen pond and recirculating system

\begin{tabular}{lll}
\hline Production parameter & $\begin{array}{l}\text { Protected } \\
\text { Earthen } \\
\text { pond }\end{array}$ & $\begin{array}{l}\text { A unit of } \\
\text { recirculating } \\
\text { System }\end{array}$ \\
\hline Stocking density & 49,000 & 49,000 \\
Rearing period (days) & 21 & 21 \\
Harvested fingerlings & 8,263 & 38,920 \\
Survival rate (\%) & 16.86 & 79.43 \\
Length at harvest (cm) & 7 & 3 \\
Mean Weight at harvest (g) & $2.2 \pm 0.23$ & $0.9 \pm 0.07$ \\
\hline
\end{tabular}

Table II: Cost Analysis for the Nursery Rearing of Catfish within Protected Earthen Pond and Recirculating

\begin{tabular}{lll}
\hline Production parameters & $\begin{array}{l}\text { Protected } \\
\text { Nursery Pond }\end{array}$ & $\begin{array}{l}\text { A Unit of } \\
\text { Recirculating } \\
\text { System }\end{array}$ \\
\hline Stocking Density & 49,000 & 49,000 \\
Cost of Feeding (N) & 10,000 & 10,000 \\
Electricity (N) & - & 2,000 \\
Cost of Diesel Fuel (N) & - & 15,000 \\
Labour (N) & 7,000 & 7,000 \\
Harvested Fingerlings (N) & 8,263 & 38,920 \\
Unit Price (N) & 12 & 8 \\
Total Sales (N) & 99,156 & 311,360 \\
\hline
\end{tabular}

Table III: Comparative profit margin of nursery rearing of catfish within protected earthen pond and recirculating system

\begin{tabular}{lll}
\hline Production parameters & $\begin{array}{l}\text { Protected } \\
\text { Nursery Pond }\end{array}$ & $\begin{array}{l}\text { Unit of } \\
\text { Recirculating } \\
\text { System }\end{array}$ \\
\hline Expenditure (\#) & 17,000 & 34,000 \\
Sales (\#) & 99,156 & 311,360 \\
Profit (\#) & 82,156 & 277,360 \\
\hline
\end{tabular}

\section{DISCUSSION}

According to Jamu and Ayinla, (2003), one way of achieving high production intensities is through the use of recirculating aquaculture tank systems. It is quite obvious from the results that the most delicate aspect of catfish fingerling production is the management of frys. The survival rate could be zero if hatchlings are not adequately catered for. Once the larva or fry hatches from the egg and depletes its yolk reserves, its survival depends both on management and culture system used. The main problem encountered with fingerling/juvenile production in earthen ponds was the poor survival rate of fish. In the present study; 49000 frys were stocked in the earthen pond; but 8263 fingerlings were harvested (Table II). It has been suggested that the lack of appropriate feed and the presence of predators were the most likely causes of this mortality (Kay and Edwards, 1999). Survival rate was higher in the recirculation system $(79.4 \%)$ relative to the earthen pond (16.9\%). However, intensive aquaculture brings with it high energy costs, necessitating the design of energy-efficient systems. The energy cost for rearing frys in earthen pond was zero and N17, 000 for recirculation system (Table II). The cost of rearing frys in a recirculating system was twice that of rearing them in an earthen pond, however, the profit margin (Table III) justifies the increased production costs. Catfish farming in farm ponds is both technologically and economically feasible for small scale producers provided they have access to retail markets that pay a premium for fresh/live product. This form of aquaculture is also suitable for part-time or hobby farmers with little expertise in pond management, who might want to produce limited quantity of catfish for home use (Engle and Stone, 2002).

\section{CONCLUSION AND RECOMMENDATIONS}

In Nigeria, fish production is low and could potentially contribute much more to rural economies. The first priority is to promote the adoption of fish farming on a wider scale, either for home consumption or for income generation. The technological options so far extended have not been sufficiently integrated within indigenous knowledge systems to establish a solid and consistent farmed-fish production base. The major constraint is the energy requirements for recirculation systems, however, the returns justify the additional cost incurred. To accommodate the market demand and to secure high price; the production system must ensure excellent taste, uniform and standard appearance of the product and reliable supply on a year round basis.

It is therefore recommended that:

- The recirculation system should be employed for mass production of fingerling 
to boost production capacity of farmers.

- The Government should look into the supply of steady and cheap source of electricity to the populace to lower the cost of production in recirculation systems.

- Low interest loan programs should be made available to social groups for aquaculture

- Government involvement to encourage growth of aquaculture by building public hatcheries to step-up supply of juvenile to small farms.

- Governmental support for aquaculture research, training and education, environmental monitoring, hazard analysis critical control points (HACCP) training, and demonstration/development projects.

\section{REFERENCES}

ADEYEMO, O.K. and FALAYE, A.E. (2009): Disease Considerations in Cage Culture. In: Federal Department of Fisheries and University of Ibadan Ventures Limited Sponsored "Capacity Building Workshop on Fish Cage and Pen Culture in Inland
Waters of Nigeria" $86-99$

ENGLE, C.R. and STONE, N. (2002). Costs of small-scale catfish production. Southern Regional Aquaculture Center Publication Number 1800, Delta Research and Extension Center, Mississippi State University, 127 Experiment Station Road, Stoneville, MS.

FAO (1999): Fishery Statistics: Aquaculture production. FAO Fisheries Series No. 58. FAO, Rome, $178 \mathrm{p}$.

HECHT, T. (2000): Considerations on African aquaculture. World Aquaculture 31(1): 12-19.

JAMU, D.M. and AYINLA, O.A. (2003): Potential for the development of aquaculture in Africa. NAGA, WorldFish Center Quarterly Vol. 26 (3): 9-13

KAY, R.D., and EDWARDS, W.M.(1999): Farm Management, 4th edition. McGraw-Hill Company, New York, New York.

OLALEYE, V.F. (2005): A review of reproduction and gamete management in the African catfish, $C$. gariepinus (Burchell). Ife J. Sci. 7 (1): 63-70.

PILLAY, T.V.R. (1990): Aquaculture: principles and practices. Fishing Book News, London.

WATANABE, W.O., LOSORDO, T.M., FITZSIMMONS, K and HANLY, F. (2002): Tilapia production in the Americas: Technological advances, trends, and challenges. Reviews in Fisheries Science 10 (3-4): $465-498$ 